\title{
Mixed connective tissue disease
}

INSERM

\section{Source}

INSERM. (1999). Orphanet: an online rare disease and orphan drug data base. Mixed connective tissue disease. ORPHA:809

Mixed connective tissue disease (MCTD) is a rare connective tissue disorder combining clinical features of systemic lupus erythematosus (SLE), systemic sclerosis (SSC), polymyositis (PM) (see these terms) and/or rheumatoid arthritis (RA). 